DOI: $10.20472 / S S .2016 .5 .3 .003$

\title{
BUILDING SOCIAL CAPITAL: A GRASSROOTS LANGUAGE PROGRAM FOR REFUGEES AND POLITICS OF INTEGRATION
}

\author{
LIKA RODIN, ANDRE RODIN
}

\begin{abstract}
:
With the increased migration stimulated by economic transformations and political unrest in different parts of the globe, the issue of cultural and economic integration of newcomers has become pressing for hosting societies. Apart from state-sponsored integration projects, various grassroots initiatives have started to emerge. This study looks at the format and effects of an informal education programme for refugees titled 'Capture the Moment and Learn Something New', organised by a person with a foreign background in a small-sized town in western Sweden. Through qualitative network analysis, we demonstrate ways in which the programme facilitates the development of interconnections within the group of newcomers and formation of a shared identity of a migrant, simultaneously helping acquisition of cultural fluency and social recognition that might improve immigrants' chances in establishing ties with the local ethnic majority. The notion of social capital is employed to explain variations in the range of resources potentially available for the newcomers.
\end{abstract}

\section{Keywords:}

social networks, co-ethnic and cross-ethnic ties, ideology, civil society

JEL Classification: 131,138

\section{Authors:}

LIKA RODIN, University of Skövde, Sweden, Email: lika.rodin@his.se

ANDRE RODIN, Swedish Migration Board , Sweden, Email: andrerodin@hotmail.com

\section{Citation:}

LIKA RODIN, ANDRE RODIN (2016). Building social capital: a grassroots language program for refugees and politics of integration. International Journal of Social Sciences, Vol. V(3), pp. 41-60., $10.20472 /$ SS.2016.5.3.003 


\section{Introduction: The quest for integration in Sweden}

During the last few decades, the main motivation for immigration to Sweden has changed from work-related to family- and asylum-related (Schierup, Hansen \& Castles, 2009: 198ff). In distinction to previous asylum streams, more individuals are arriving from outside Europe, and fresh prognoses do not foresee any change in this pattern (Swedish Migration Board, 2015). Asylum immigration to Sweden has also increased to become among the highest per capita in Europe (INDIAC, 2014). In this context, political debates and public policies have sharpened focus on the issue of social integration of newcomers. From the beginning of $20^{\text {th }}$ century, social integration in Swedish public sphere is increasingly associated with 'structural assimilation' that builds on immigrants' establishment in the labour market. Although more traditional discourse of 'acculturation' is evident in Parliamentary debates, public opinion screenings and innovative educational practices such as semi-obligatory courses for immigrants on national culture and social organisation (Johansson Heinö, 2011). The state is assigned the primary responsibility for immigrants' (economic) integration with an emphasis on guaranteeing social justice (ibid.). This mission appeared to be challenging. Along with increasing economic deregulation, the general difference in related resources with present-day immigrants has had an aggravating impact on the scope for immigrant integration in Sweden when it comes to employment, housing and education (Ekberg, 2006; Integrationsverket, 2002). The integrative measurements and actions covered by state institutions have also not been too successful (Riksrevisionsverket, 2015). The deficiencies in immigrant integration are therefore assessed as a pressing and important issue both in political and scientific discourse (Lundh, 2010).

In this context, grassroots initiatives have started to emerge as sites of social entrepreneurship. The present study looks at the format and effects of an informal education programme for newly arrived immigrants named 'Capture the Moment and Learn Something New', organised in a small-sized town in western Sweden. Through qualitative network analysis, we demonstrate ways in which the programme facilitates the development of interconnections within the group of newcomers and formation a shared identity of a migrant, simultaneously helping acquisition of cultural fluency and social recognition that might improve migrants' chances in establishing ties with the local Swedish community. The notion of social capital is employed to describe the range of resources accessible to the individual or a group through connection to a certain network (Portes, 1998; Lin, 2000). As further demonstrated, the programme leader functions as a 'social broker' (Burt, 1992, 2004), establishing and mediating connections between the local community and the migrant group.

\section{'Capture the moment and learn something new'}

The education programme (hereafter 'Programme') was launched in early spring 2014 by a former immigrant who is also a teacher for newly arrived immigrants. It has been 
running every week for three terms. The teacher got the idea behind the Programme during a one-day study trip arranged by the municipality and a local NGO. At this occasion, a group of immigrants was given the opportunity to visit regional attractions, including a swimming hall in a nearby town. The visit to the swimming hall turned out to be a disaster. According to the teacher, many of the participants in the study trip demonstrated a very limited understanding and consideration towards the establishment. They made noise, disturbed other guests and did not obey the established rules even when asked to do so. The overwhelming experience motivated the teacher to launch an education programme for newcomers. It was legitimized by the local authority and assisted to some extent by the local Protestant church.

According to the Programme leader (personal communication, 13 May 2015), the main objectives of the educational sessions include:

- creation of 'a meeting place for people... regardless of origin and religion';

- motivation of immigrants towards purposeful, active and responsible living;

- fostering respect for differences and tolerance as a mean of preventing 'religious fanaticism' by training in the art of listening, understanding and discussing;

- $\quad$ help those with traumatic life experiences that can lead to aggression and unrest;

- $\quad$ enhance positive thinking and gratitude to others;

- $\quad$ stimulation of interest in learning Swedish and providing initial support for this; and

- $\quad$ assisting an exploration of the national culture and local community system.

As summarised by the teacher, 'I have worked hard with them [trying to convey] that they should dare to feel trust and future faith, that they can become part of Sweden and not be against Sweden' (ibid).

The Programme takes the form of a two-hour lecture every Sunday evening in the town parish house. The lectures broadly consist of two parts: language training and theatre plays. Meetings are typically held in several languages-Arabic, Swedish and English-with prevalence of Arabic since most of the groups turned out to be Arabicspeaking. Sentences and expressions are given in Swedish first and then translated and explained in Arabic. Theatre plays are performed in Swedish. The texts and plays in the Programme mostly carry what we may call 'moral messages' about the rules of life, how to treat each other, to take responsibility and to appreciate what one has. The text excerpts are usually taken from biblical and other religious sources, but also from popular texts and proverbs such as 'Chinese wisdom', 'folk tales' and the like. The Programme ends each term with a celebration party, to which town inhabitants, business representatives and local authorities are invited for food and theatre.

The number of participants varies over time, but usually amounts to between 15 and 30. Most of them are between 20-60 years of age; both men and women are represented. An informal rule is that one participates only during one term, but it seems that many prefer to come back for subsequent terms. 


\section{Network-based social capital in theory and research}

The study employs a notion of social capital actively developing within social sciences during the last decades. Contemporary 'neo-capital' theorisations (Lin, 1999: 29-30) approach social capital at macro- and individual levels, emphasising the role of social ties and relationships of trust or resources in the terms of Robert Putnam and Pierre Bourdieu, respectively. Moreover, a specific trend-a network-based theory of social capital-has emerged that focuses on (inter)connections between individuals and formal and informal institutions (Lin, 2000, 2008). Lin (2000: 786) defined social capital predominantly in terms of assets associated with a specific network being simultaneously irreducible to it, as 'investment and use of embedded resources in social relations for expected returns'. This includes 'information,' 'influence,' 'social creditably and reinforcement' (Lin, 1999: 31). In terms of profits, analysis can be directed to 1) 'accessed social capital' or resources associated with a specific network and potentially available to its members by virtue of membership and 2) 'mobilized social capital', a notion that stands for real gains of an actor's telic efforts to utilise the network resources for specific ends via opted bonds (Lin, 2008: 52ff). These two factors combined are seen to constitute the value of social networks. The theory further differentiates between a system of linkages (network) and resources associated with it (social capital). A network serves as a tool for attaining certain assets; its features should be assessed within a particular context (ibid.).

Variations in a network's characteristics, such as depth of relationships and their mutuality, are imagined as a layered system. Lin (2008: 59ff) suggests distinguishing between 'binding', 'bonding', 'belonging' and 'bridging' types of network relationships to signify family/kin ties, mixed-type 'social circle', institutionalized identity-generating links and cross-network connections, respectively. Binding and bonding ties were found especially functional for emotional coping and maintaining an individual's daily life. In situations that demand involvement of new assets, however, those bonds can appear of limited use due to operation of the homophily principle: Partners of networked interactions tend to be quite alike, when it comes to status or resources. Trans-network connections then appear to possess special value, creating opportunities for a flow of information and other resources across 'structural holes' (Burt, 1992, 2004; see also Lin, 1999, 2008).

The theory of social capital, including its network-based variation, is well integrated into migration research. Characteristics of ties can have both positive and negative effects on social capital and network-based revenue (Breton, 1964; Brisson \& Usher, 2005; Cederberg, 2012; Kindler et al., 2015; Nannestad \& Svendsen, 2008; Portes, 1998), facilitating a process of social inclusion or exclusion already inscribed in the network's structural positioning (Lin, 1999, 2000).

\section{Study methodology}

Mainstream studies on social capital are carried out in quantitative tradition (Svendsen, 
2006), which seems to be especially pronounced in network-based research, since network analysis is primarily affiliated with the disciplines of mathematics and statistics

(Luke \& Harris, 2007). It operates with categories of 'nodes/actors' and 'ages/relationships' (ibid.) and strives to assess connections among individuals, social positions or social groups (Lin, 1999). As an alternative to the dominant positivistic paradigm, an interpretive network approach has recently emerged. Svendsen (2006) studied integration of internal migrants within a Danish municipality and proposed a more flexible, open and explorative methodology based on unstructured and semistructured interviews and observations. Directed by the idea of social capital as 'inseparably related to concrete discourses, social classifications, and identities in a specific time-space context' (p. 42), the scholar gradually moved from traditional 'network mapping' towards in-depth description of sources and mechanisms of social and (self)isolation and social marginalisation. The data were organised in several thematic niches and analytically displayed in a chart.

The current study undertakes and develops the open and inductive model suggested by Svendsen (2006). It utilises a case-study design that builds on collection and analysis of various empirical materials (Creswell, 2012). The research data come from twelve semi-structured interviews with current and former Programme participants, interviews and multiple communications with a Programme leader, and interviews with local church staff and several participants of the celebration party. Moreover, eleven hours of participant observation were conducted during the group meetings at the town parish house on Sunday evenings and at the celebration ceremony at the end of the Programme in early summer 2015. Video records of another two parties (summer 2014 and winter 2015) were provided by the Programme leader. All the materials were converted into textual format, coded and analysed in regards to theory-informed meaning patterns. The study followed the established ethical guidelines for qualitative research in social sciences as defined by the International Sociological Association Code of Ethics (2001).

\section{Results}

Interviews and observations were carried out in May and June 2015. Seven interviews were conducted with female and five with male immigrants who have mainly stayed in the country from half a year up to three years, with one respondent having been in Sweden nine years. Respondents with foreign backgrounds were between 18 and 55 years of age, housed at rented flats in the town, at the refugee camp or town refugee accommodation. Representatives of the ethnic majority were 55-80 years old, two women and a male local church staff member.

In the presentation that follows, we describe the phenomenon of the Programme by organising the obtained data into three theory-inspired categories: social network, social capital and network-based revenue. 


\section{Social network}

The majority of immigrants waiting for a resident permit are placed at a refugee camp situated in a remote part of the town; here many of interviewees came to know each other. The refugee camp hosts people from different countries and up to twenty different languages might be spoken there. One of the participants reported difficulties in communication between individuals due to differences in language. NGOs sporadically took the initiative in bringing immigrants together on a picnic or to a restaurant. With the help of a translator, people could make some initial contacts with one another on such occasions. But more frequently, nothing much was reported to happen at the refugee camp: People were 'just sleeping and eating, eating and sleeping, sleeping and eating' (Interview Participant/ IP12). According to the national regulation, one can apply for a Swedish language course or society introduction courses only after receiving an identification number, and the paperwork can take up to several months. During this time, some interviewees felt increasing detachment from others, loneliness and frustration.

The majority of participants learned about the Programme from the teacher who visited the refugee camp and presented to the inhabitants its general idea. The Programme leader also advertised the educational initiative at the local school where she was teaching, as well as among relatives and acquaintances with foreign backgrounds. Several participants indicated that initially they have become involved in the Programme due to the lack of other types of activities available to them and lack of contacts with other migrants and local community. Recognition of the importance of language and culturally specific knowledge may come somewhat later.

\section{Spaces}

There are several spots where migrants can meet other newcomers and members of the local ethnic majority, including the refugee camp, family residence area, school and gymnasium, church, sport clubs and community facilities (library, stores, hotels, playgrounds). Those can work distinctively in terms of facilitation or complication of coethnic and trans-ethnic networking. Two examples will be considered, a local parish house and a food store.

The very location of the meetings-a parish house-appeared to be an obstacle for some individuals in joining the Programme, particularly those with Muslim backgrounds. A Protestant church was seen as an inappropriate space, and visiting it would require permission from the Muslim religious authority. Challenged to try by one of their Christian counterparts, several Muslims eventually started to attend the study circle. In quite a distinctive manner, the interviewed church representative defined the parish house as a 'neutral space', as a general assembly site where everyone can come, while church was assumed to be a specific ideological domain. Thus, misrecognition of the parish house by some migrants as a particularly marked symbolic 
space might restrict their opportunities to engage in the Programme and thus work as a separating factor.

Other spaces, such as a local food store, might be seen as facilitating interconnection between individuals in the local context, including the Programme participants. A food store-almost the only shopping place in the town-appeared to be among the main attractions for the local community and especially for newcomers who have not yet developed full orientation in the social cultural environment. Here, newcomers can meet each other quite frequently or can visit the shop together as a part of socializing. The Programme itself, a story was told, got its impetus due to a meeting at the food store between the Programme leader and a group of migrant women. The teacher experienced shortage of resources and planed to stop the Sunday sessions after the first term but was persuaded by the women to continue for another term. Women expressed their concern about limited opportunities to meet others, practice language and maintain general psychological well-being.

Ties

Even if many of the interviewed newcomers had some initial contacts in Sweden, the task of creating their own engagement in existing networks remained central to all study participants. The Programme facilitated development of new ties both within the immigrant group and across ethnic boundaries with the wider community.

As reported in the interviews and confirmed during observation, interactions among participants took place during the Sunday meetings, but those were rather fragmentary and notably shaped by age and gender: Women interacted predominantly with other women and young people with others of the same age. Lectures were on average quite intense, but there was a space for spontaneous exchanges during preparation and a coffee pause. Group discussions were frequently carried out in native languages (mostly Arabic), which might frame interactive patterns among the participants. Several respondents also indicated they were building more stable relationships that went beyond the context of the study circle. Younger people can go out together to attend sport events (e.g., football, billiards). They were also more likely to attend the same school, which would strengthen interconnection. Middle-aged individuals might develop friendships with 2 or 3 other families from the same country. They might occasionally go shopping together, cook, discuss daily issues of school life to their children, and train in Swedish and other languages. Some families still live in the refugee camp, where space is usually limited. Then those who already have a flat in the residential area could invite others to their 'proper' home to sit and talk in more comfortable conditions. Thus, the Programme functioned as an important domain for establishing ties among immigrants, but not the sole domain. The effect was reinforced by linkages between individuals through other institutions and contexts, especially housing and education. 
The more challenging issue was meeting Swedes. Several life situations facilitated the migrant's interactions with local residents, including neighbours, teachers at school, staff at the refugee camp, church members, representatives of NGOs, participants of various sport activities and finally the audience of the final celebration. The Programme participants appeared rather open and active in contacts with individuals perceived to be members of the cultural majority. Our initial observation was very representative in this sense. Already during the first Sunday meeting at which we presented our study, obtained consent for observation and invited people to interviews, several participants initiated individual conversations with us together or separately. One young man inquired about an educational institution with which one of us is affiliated: what kind of disciplines and programmes exist, where to find more information. He was planning for higher education. A woman who seemed to be somewhat shy about speaking Swedish brought her small daughter to our table. We had our small son with us on this occasion, and the children were drawing something together, communicating in a simple manner. The situation demonstrated that supposed access to social capital is not always enough; one should be capable of mobilizing the embedded resources (in terms of Lin, 2008). Being limited in language fluency, the woman had to invent alternative means for a desirable interaction. Analysis of video records from closing parties also suggested that those migrants who may feel uncertain about their own capability to communicate in Swedish may shy away even in the situation of virtual opportunities to make contacts with local residents.

Overall impressions of certain difficulties in getting in touch with local residents and the need for better mutual knowledge and recognition were frequently expressed in interviews. A middle-aged male respondent said:

I think that when I talk to Swedish people, they would like to know who we are, how do we think what do we like, what do we need. We respect them, but there is no chance to meet each other, I don't know why. Maybe when I work, I will meet Swedes and we will learn about each other. (IP12)

One of such meeting opportunity was associated with housing. Several interviewed migrants indicated that they attempted contacts with Swedish-born neighbours with different degrees of success. Two female respondents reported good relationships with their neighbours, which were especially likely if they shared the same house and had some other occasions to intersect, for example, at school. In these interactions, newcomers can get help with Swedish and occasionally with job search. More frequently, however, such contacts are limited to 'small talk' and exchanges about cooking tips. One male respondent indicated a failure in establishing relationships with his neighbours, an elderly couple with one partner in a wheelchair. The man asked whether they would like him to help sometimes and received a negative reply, which was somewhat frustrating for him.

Meetings at the local food store were also described as rather common and superficial. At the shop, migrants can encounter former schoolteachers or refugee camp staff 
mainly with greetings and 'light' conversations. A former teacher described her frequent conversations with a female refugee who once attended her classes:

She seems happy and friendly when we meet, sometimes in a hurry, just like me. But we go into the store often, standing at the fruit counter, for example. I ask about how things are going with the little one [a child], and she basically tells me how it is. I asked sometimes also on the progress of studies and work, but I do not anymore because it had never previously happened very much there and it feels a little uncomfortable to press on with such issues. Especially as it is me who asks and not she who tells voluntarily or asks something about it.... ask and she responds, then we go most often in opposite directions because we are going to buy various goods. (IP14)

Mutual fears and anxieties, as well as 'we versus them' discourse were also present in respondents' accounts. One of the interviewed refugees pointed out that the geographical area in which he was placed is well known for high popularity of rightwing politics, even though he could not detect this pattern in interactions with local residents; everyone seems to be nice and friendly. At the same time, the interviewed church staff expressed concern about religious radicalism associated with certain belief systems and highlighted positive effects of the Programme:

[l]f someone is from /Middle East/, you never know really...who they are. They feel this themselves also, that extremism may be on the way, quite hidden. So...I know that it has been strained at times but it is an incredibly good integration work. Partly they feel wellreceived, they feel they can relate to us and create a community with us and they feel they can do something too. (IP1)

The final Programme celebration is yet another occasion for meetings between local residents and newcomers. At the party during the first study cycle, several refugees presented themselves in Arabic (the Programme teacher helped with translation) and in emerging Swedish. Younger newcomers talked about their success in learning the language and making friends; middle-aged, educated migrants emphasised their desire for mutual knowledge and cooperation with locals, as well as hope for decent living opportunities and standards in the new country. The theatre play had a double function. From the one side, it was supposed to summarise for the study group what was done during the term. From the other side, the spectacle demonstrated to the local residents that newcomers were familiar with western moral standards and could perform in a recognizable manner.

Messages translated by the theatre performance might be perceived by the local residents as somewhat idealistic, like the remarks of a party guest:

In a way, the content is trivial, at least for me. Sure, everyone has equal worth and all that stuff, and it's important to treat everyone equally and that should help anyone in need, regardless of who the person is. Maybe it is not always so in reality, not in Sweden, nor in many other countries, including the countries that refugees come from. I mean, it's clear that it's not so much. The society treated people differently, depending on whether one is rich or not, and on the basis of gender and age and nation. But I think 
most of us probably really agree with the message of the plays and if we ask ourselves if we would probably like that it was so, that all are equal. (IP14)

Participants of the study group recognized the generalised nature of the messages mediated as well. A young man who came alone to the country while his entire family remained back home in a dangerous environment noted on the topic of gratitude: 'If you do not have a family, it's not easy to be grateful' (IP3).

Is it possible to establish contacts with a Swedish-born person at the party? Several of the interviewed migrants reported communicating with local residents in some way at the celebration. As noted during an observation session and in analysis of video records, the audience was rather loosely clustered, with some natives and migrants occasionally mixing with one another. Relatively segregated were foreign-born mothers with small children. One of participants, a middle-aged man who had come to the country quite recently but had progressed well in the language, reported having a good conversation at the party, followed by a home visit to a family of a local resident. But more frequently, communication seemed to be somewhat formal and sketchy from both sides. There is a certain etiquette to be followed. The interviewed elderly Swedish woman noted that she felt a need to be introduced by someone to new people. The interaction that followed was not easy either, since the conversational partners did not have much in common. Another respondent-a local resident-reported being involved in 'small talk' with a refugee she sat by. The conversation stopped when a coffee break was announced, and the woman headed towards the hall where refreshments were served.

The celebration ceremony is also thought by the organisers to be an occasion at which one can meet local politicians, representatives of NGOs and local businesses to voice their needs and establish connections that can help in job searches and other individual and collective issues. Some representatives of the local administration were present at all three parties, although Programme participants expressed disappointment over the rather limited interest in their activities from the authorities and business organisations.

\section{Nodes}

Two actors were frequently named as significant nodes in cross-ethnic networking, a church representative and the Programme leader. The church representative came initially to check out what was happening at the Programme and stayed with the group through the first two study circles, facilitating discussions with language and intellectual contributions. The Programme participants reported developing more personal relationships with the man outside the Programme activities, including playing football, home visits and assistance with various practical issues. Still, his integration into the group was experienced as partial and somewhat paternalistic. 
The Programme leader certainly played a central role in the migrants' local network. All participants indicated they were connected to the teacher and via her to one another, the local community and some of important institutions. Her multi-language proficiency, personal experience of refugees' road into Swedish society, enthusiasm, entrepreneurial spirit, outstanding energy and will to help others made the teacher especially popular and trustworthy among the newcomers. Burt $(1992,2004)$ used the notion of 'social broker' to describe an actor organising and systematising interactions across loosely connected groups of people ('structural holes'). Social brokers facilitate diffusion of information, novelties and resources. The Programme leader engaged in broadcasting cultural and social information for the migrants and facilitating interactions with local authorities, NGOs and business actors aimed at supporting Programme activities and solving practical issues for participants.

\section{Social capital}

Research on social capital tends to assess resources embedded in the network in terms of 1) emotional support and 2) practical help, i.e., assistance in job search (Lin 2008). We attended to those features of networking as well. The study further highlighted the role of insocialisation of a particular value frame that can mediate access to the resources potentially available for the network actors.

\section{Affective and instrumental support}

The Programme brought together refugees during their initial period of adaptation in the new country. For many, this experience was challenging, and for some, even frustrating. A possibility to meet during Programme sessions with compatriots going through similar stages of adjustment was seen as helpful. Discussions in class and outside the educational context occasionally involved dynamics of a self-help group.

\section{Instrumental support}

At the moment of interviewing, a majority of the participants were not directly concerned with job searches; language proficiency instead was a dominant focus. Among a few jobholders, one woman was working in the family business, another was in a cleaning service and the third one with a university diploma got an opportunity to teach Arabic-speaking students at the local high school, a placement found via relatives of a neighbouring Swedish family. But even for those who were employed, language fluency constituted the main concern as both a resource in itself that can be acquired by interactions with others (native speakers first of all) and as a factor conditioning the very possibility of such contacts. Interactions with local residents were appreciated among the respondents who perceived Swedes to be nice and friendly, but not very open to contacts with newcomers. 


\section{Cultural capital}

Culture-specific knowledge and skills mediate one's opportunities in cross-ethnic interactions and networking. This included proficiency in Swedish language and a particular value system.

\section{Language}

Language practice was the major objective of the study circle. During observations, it was difficult for us to establish to what extent the didactical format undertaken may benefit the participants. A fast tempo, loading of classes with different types of information, loosely structured interaction and relatively large numbers of other languages employed (Arabic, English) might be seen as aspects differentiating from the dominant model of teaching-learning. However, the majority of the respondents indicated satisfaction with the language training they received. The very context motivating to use Swedish was appreciated, since frequently refugees had rather limited opportunities to use the new language and thus master it. Many indicated that they speak Swedish just couple of times a week (in a shop or at the doctor's office), while migrants' daily interactions were usually with family members and in their native language. A female respondent who went for an initial course in Swedish but currently was staying home with a child indicated that she has to struggle to maintain her language skills:

When we meet each other and talk to each other we can develop in Swedish, so it is very good. I am at home now on parental leave and when I go to the meeting I talk some

Swedish. It is very good to talk Swedish and learn the language. Not forgot what I've learned from the /previous course/. (IP2)

Younger respondents might have some opportunities to speak Swedish at school, but expressed a general concern over the shortage of such practice. Apart from language, fluency in national cultural codes was seen as an important asset associated with Programme participation.

\section{Ideology}

A particular ideology based on ideals of tolerance, conflict avoidance, participation, justice, respect for law and individualism constituted a part of cultural expertise that migrants were expected to obtain alongside knowledge of cultural rituals and traditions. This was seen to a prerequisite for integration. A female participant explained the idea of the Programme and its effects:

We talk about how we treat other people, and that we treat each other in a good way. And we can get on in society only if we learn that there are other people that we need to treat in a good way....We are also studying Swedish, reading and talking about the Swedish culture. And we read that there are not only rights of a community but also 
obligations.... I have learned to accept other people's opinions and not think that they are stupid or get angry, or stop talking to them....Before I came here, I mostly hung out with people like myself, and I thought that people with other opinions were wrong. Now I am more integrated. (IP6)

Training in tolerance was especially important due to the pronounced religious heterogeneity of the migrant group. As indicated earlier, the Programme leader utilised biblical stories to exemplify value-claims, even though the study circle was advertised as an alternative language course. It appeared at times a challenge to manage interactions in the diverse audience composed of both Christians and Muslims of different orientation. Some participants left the class and never came back; others learned a new mode of interaction (individualism, attentiveness and respect) and the art of self-discipline that helped maintain relative peace and balance in a multicultural context. A male respondent indicated that he developed a habit of being open in his opinion and towards other viewpoints in general, simultaneously avoiding controversial topics:

Everyone is responsible for oneself, don't go to others' business. From the start of the Programme, we learned to be open and integrate in the society we live, not just go with our own ideas.... am open in general, but if it seems that a person may create a problem, I don't go for this kind of discussion. In Swedish society everyone has a freedom to say whatever one wants. I know several people who with 'fanatic backgrounds'. I don't want to open such a discussion with them. (IP12)

Overall, the enhanced experience of discussions, an opportunity to talk about a variety of topics that some individuals could never raise in their home country, was enriching and empowering. Those discussions have in time become increasingly productive with the incorporation of the Programme participants' affirmation of acceptance and nonconflict exchange.

The training seems to be quite successful with 'all those words and gestures that get stuck in your mind' (IP7). Even very young participants took part in the transformative processes. A story circulated in the group about a child attending the classes with his parents. He learned his first phrase in Swedish-'treat others as you would like to be treated yourself'-and was proudly repeating it to adults with an immediate note that he did not know for sure what this meant. Theatre plays could be seen as the most effective and thus the central tool for internalization of the specific value system. Biblical tales were carefully selected by the teacher to represent different life situations and variations in moral choices. Performances were practiced for several weeks at the Sunday meetings, even if the presence of the actors involved was rather fragmentary. Some performers seemed to come for the first time directly to the stage. The church representative who attended Program meetings contributed to preparation for the performance with suggestions on chorography. Men were overrepresented in the theatre group, with an exception of three young women. Women with small children preferred to stay in the audience, being engaged, however with the discourse maintained. As one female who did not participate directly in the artistic practices 
explained their objectives with a reference to a biblical story about a woman caught in adultery:

There is a purpose behind every play, deep ideas about your own life. It is important to use this language and this thinking. In some countries they used to make direct judgements and punish a person, probably to death, without law. I call this violence. Without showing to a person what I call forgiveness, without reporting to police that the person did wrong—no, they make own judgements. It is wrong. (IP11)

Another respondent emphasised the role of language in acquisition of the new moral perspective:

One learns to speak properly, so people can understand what it is they say. When playing theatre you must speak correctly, and you can use the hands and body when you should show something and not just with words. One can learn to imitate words, so you can articulate them in a good way. (IP6)

In critical tradition, 'speaking properly' is closely associated with ideological training and the process of subjection-subjectification (Butler, 1995). Reproduction of the existing socio-economic order demands preparation of the labourers through education aimed at fostering a number of important competences (Althusser, 2008; Butler, 1995). 'The skill of speech' is seen by Butler to be central. Since proficiency and obedience go hand in hand, training unavoidably deepens one's subscription to the dominant ideology.

\section{Network-based revenue}

Four types of Programme outcomes were identified in the current analysis: identity building, trust, cohesion and political participation.

Identity

The Programme as a whole and the final celebration worked to bring together individuals with different ethnicities, religions, genders and class backgrounds to build a shared identity of a 'good migrant' who would associate him/herself with the dominant liberal discourse and demonstrate a will to contribute to the life of the hosting society. As mentioned above, the party addressed the group itself no less than the audience. It ended with a dance in which refugees from different countries joined together. Their loosely coordinated movements dramatically contrasted with a highly harmonized greeting song spontaneously performed by Swedes attending the event, mainly strangers to one another. The two spectacles happened in close proximity and demonstrated a profound distinction between the emerging collective self-definition of the newcomers and well-established (and well-mastered) identity of the local residents. 


\section{Social cohesion}

Social cohesion is frequently considered as an index of a community's welfare (Delhey \& Dragolov, 2012) and an effect of social capital (Starrin \& Rønning, 2011). One Programme participant associated social cohesion with a specific 'atmosphere' produced by means of theatre play:

I can not fully explain [the idea of the theatre], but that's about that we should create a good atmosphere in /the town/....That all can participate and that it is important that we do something, and that you should not just be at home, and in school and not be involved in the community. We'll be more together, and we get to meet each other, and it provides a great atmosphere. I think that is the background to the theatre. (IP5)

In a similar manner, a local woman participating in the celebration put forward the idea of cohesion as an effect of the theatre performance:

I do not know what they really mean, but maybe it's a way to make participants feel like they should be a part of Sweden and not feel left out. That they should get along with each other well? They sit in the same boat and that they should help each other and not continue the conflict they once tried to leave? Perhaps it is this that pieces should be about? But it was also things about that you should be grateful and not complain too much. Perhaps there is something in it too? Many refugees I've met complain about pretty much everything, but it can never be as it was in the home country, for better or worse. The thing's clear, and perhaps therefore it is good to accept some things anyway, and do not hold on too much. (IP14)

By mastering 'speaking properly' and in a particular manner, by interacting in the process of the training, the newcomers have good chances to obtain a sense of unity both with their fellow refugees and with the wider community. In fact, the majority of the interviewed newcomers stated that they want to 'integrate' themselves into the life of Swedish society.

\section{Trust and social participation}

In the interviews, trust was associated with society's care for migrants. Several respondents were convinced that Sweden needs migrants and they are going to ensure the country's future. That is why the attention of local authorities to the migrants' situations and needs was seen as essential, including creation of a friendly atmosphere and facilitation of educational or other developmental activities. In this respect, the Programme played a crucial role in providing a space where authority can come to see that 'there are people to take care of' (IP12).

Many had not felt themselves yet to be a part of the Swedish nation. Others were somewhere in between their previous national affiliation and the new one, occasionally longing for their lives back in the homeland. Several reported following the news on TV, although their main concern was getting information about the position of migrants in Sweden or migrant-driven organisations. One male respondent indicated a wish to 
join a political party in the future. The idea was voiced as well that people with nonSwedish backgrounds should be more actively involved in policies and practices addressing social political issues and education for foreign-born community members.

\section{Discussion and conclusion}

The current integration framework in Sweden represents a dramatic departure from the ideals of multiculturalism that had dominated the political sphere during 1960-1980s. Nowadays, the approach rests on a request for one's economic self-efficiency (Johansson Heinö, 2011). Alongside involvement in productive practices, immigrants are expected to form a new national identity based on Swedish language proficiency, familiarity with cultural traditions and loyalty to the dominant value system. Thus, certain indications were found that assimilation discourse might constitute a 'hidden agenda' in integration debates and policies, which is especially pronounced with respect to debates on integration of Muslims (ibid.). In this paper, we employed a network-based analysis to scrutinise a civil society initiative aimed at helping refugees during their initial period in the new society. As we concluded, it worked as a preparation for the immigrants to the process of integration, framed primarily in terms of acculturation and social inclusion, with a further perspective for 'structural integration' (Gordon in Johansson Heinö, 2011). Such a function can be especially important since, as we demonstrated in the study presentation and visualised in Figure 1 , the acquisition of cultural capital (i.e., Swedish language, cultural codes, ideology and social information) might condition one's capacity to incorporate into the existing cross-ethnic networks and mobilise resources embedded in them. Thus, for example, poorly developed language skills may restrict people's chances to benefit from potentially available contacts. At other times, cultural capital appeared to be an outcome of networking; some of the interviewed refugees reported using contacts with local residents instrumentally to improve their own cultural fluency.

Figure 1. The relationship between cultural and social capital for Programme participants

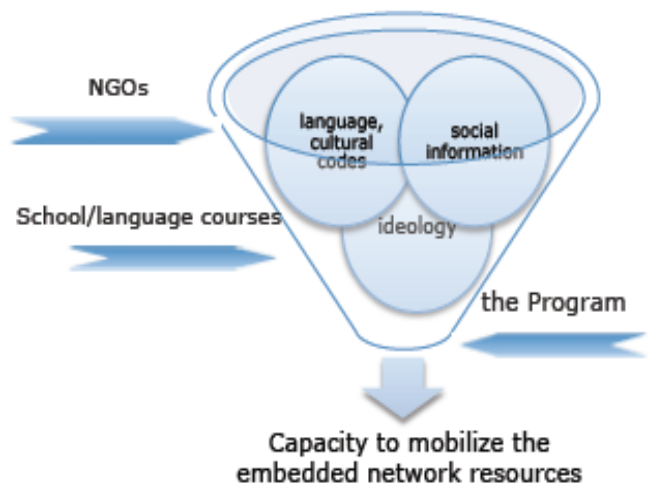

Source: The study results 
The role of ideology was especially highlighted in the initial training for refugees (displayed in Figure 2). Learning about the value system, which is grounded in aspirations of tolerance, acceptance and consensus, enables bridging between multiple co-ethnic networks and the production of a shared identity of a migrant. The theatre play carried out in the framework of the Programme might strengthen the emerging shared migrant identity as an outcome of its physical enactment. The celebration party additionally assisted the immigrants in 'impression management' (Goffman, 1959) in the face of the local community. The message broadcasted was supposed to indicate that the newcomers do recognize the established order, can perform in an appropriate manner, and are capable of speaking the same language (both in terms of linguistics and value-based directions). This seems to be something that the Programme was striving to achieve from the moment of its invention as a response to the episode in the swimming pool. The Programme leader operated both as a strategic linkage between two structurally separated networks and a kapellmeister for the 'good migrant' performance. Social research tends to present immigrant associations, grassroots organisations and other initiatives as 'corridors' to enter the wider society (Svendsen, 2006). In the analysed case, the Programme appeared rather as an interface that allows an initial encounter between immigrants and the ethnic majority to demonstrate the potentials of the newcomers in adapting to new social cultural demands. Even earlier, Cederberg (2012), working with data from interviews with refugees in Sweden, argued for the importance of cross-ethnic analysis and the necessity to account for the functional proximity of social and cultural capitals. With reference to Pierre Bourdieu's theoretical frame, the author highlighted that 'the basis for trust and reciprocity within specific networks...are culturally specific' (ibid.: $62)$.

Figure 2: The role of ideology in social integration

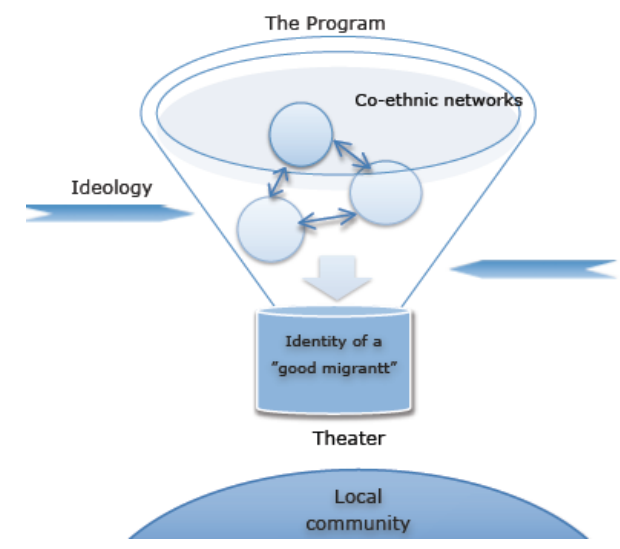

Source: The study results

Implications for methodology, policy and research

Immigrant networks are frequently analysed as homogeneous, and the main intrigue is assumed to be unfolding in their relationship to the ethnic majority (e.g., Anthias, 2007; 
Behtoui, 2008; Bevelander, 1999; Brisson \& Usher, 2005; Cederberg, 2012; Portes, 1998). This is precisely how political institutions would like to see immigrants to reduce the complexity of welfare provision (Johansson Heinö, 2011). In the current case, the group of newcomers happened to be highly heterogeneous, and thus, building of networks started with bridging the diverse ethnic groups that were divided by language and religion and other social ideologies to create a shared identity of a migrant. As demonstrated, this task was accomplished by cultivation of liberal values and attitudes among the refugees. Thus, the study points to the ambiguity of the division between bridging and bonding ties/capitals manifested itself at the empirical level (see also Cederberg, 2012).

Bonding ties are frequently defined as facilitating cohesion within a homogeneous group at the expense of the solidarity of the society at large (Svendsen, 2006). At the same time, strengthening co-ethnic networking can be seen as a 'result of failing to access networks with/in majority society' (Cederberg, 2012: 65). The current study added arguments to the importance of openness of the hosting communities to migrants. In this context, the role of grassroots initiatives is crucial in modulating social identity of immigrant groups, as was especially relevant for the case in question, and in creation of alternative spaces for encounters between the ethnic majority and the newcomers. Further research is needed on social entrepreneurship and integration agenda in relationship to state-sponsored programmes and policies.

\section{Reference}

ALTHUSSER, L. (2008). On Ideology. London \& New York: Verso.

ANTHIAS, F. (2007). 'Ethnic ties: social capital and the question of mobilisability'. The Sociological Review, Vol. 55, No 4, s. 788-805. http://dx.doi.org/10.1111/j.1467-954X.2007.00752.x

BEHTOUI, A. (2008). Informal recruitment methods and disadvantages of immigrants in the Swedish labour market. Journal of Ethnic Migration Studies, Vol. 43, No 3, s. 411-430. http://dx.doi.org/10.1080/13691830701880251

BEVELANDER, P. (1999). 'The employment integration of immigrants in Sweden'. Journal of Ethnic $\begin{array}{llllll}\text { and } & \text { Migration Studies, } & \text { Vol } 25, & \text { No } & 345-468 .\end{array}$ http://dx.doi.org/10.1080/1369183X.1999.9976695

BEVELANDER, P. \& PENDAKUR, R. (2012). Socialt Kapital och Integration i Kanada, in Peter Hojem \& Martin Hådal (eds.), Kanadamodellen - hur invandring leder till job. Malmö: Fores.

BRETON, R. (1964). 'Institutional completeness of ethnic communities and the personal relations of immigrants'. American Journal of Sociology, No 70, s. 193-205. http://dx.doi.org/10.1086/223793

BRISSON, D. \& USHER, Ch. (2005). 'Bonding social capital in low-income neighbourhoods'. Family Relations, Vol. 54, No 5, s. 644-653. http://dx.doi.org/10.1111/j.1741-3729.2005.00348.x

BURT, R. (2004). 'Structural holes and good ideas'. American Journal of Sociology, Vol. 110, No. 2, s. 349-399. http://dx.doi.org/10.1086/421787 
BURT, R. (1992). Structural Holes. Cambridge, Massachusetts and London, England: Harvard University Press.

BUTLER, J. (1995). 'Conscience doth make subjects of us all'. Yale French Studies, No 88, s. 6-26. http://dx.doi.org/10.2307/2930099

CEDERBERG, M. (2012). 'Migrant networks and beyond: Exploring the value of the notion of social capital for making sense of ethnic inequalities'. Astra Sociologica, Vol. 55, No 1, s. 59-72. http://dx.doi.org/10.1177/0001699311427746

CHAUNG, Y. \& PHILLIMORE, J. (2013). Social Networks, Social Capital and Refugee Integration. Research Report for Nuffield Foundation.

CRESWELL, J. (2012). Qualitative Inquiry \& Research Design. Choosing Among Five Approaches. (3rd ed.). London: Sage Publications.

DELHEY, J. \& DRAGOLOV, G. (2012). 'Happier together. Social cohesion and subjective well-being in Europé'. International Journal of Psychology. doi: 10.1002/ijop.12149

EKBERG, J. (2006). Immigration to the Welfare State. Is it a Burden or a Contribution? The Case of Sweden, AMID Working Paper Series 48/2006, Växjö.

GOFFMAN, E. (1959). Presentation of Self in Everyday Life. New York: Double Day Books.

INFORMATION AND ANALYSIS CENTRE/INDIAC (2014). Asylum Trends: Monthly Report on Asylum Applications in The Netherlands and Europe, August 2015. Available at:

https://ind.nl/Documents/Rapport\%20Asylum\%20Trends\%20August\%202014.pdf

(accessed 23.03.2016).

INTEGRATIONSVERKET/SWEDISH INTEGRATION (2002). Rapport Integration 2002, Norrköping, Integrationsverket.

INTERNATIONAL SOCIOLOGICAL ASSOCIATION (2001). Code of Ethics. Available at: http://www.isa-sociology.org/about/isa code of ethics.htm (accessed 8 may 2015)

JOHANSSON HEINÖ, A. (2011). Integration eller Assimilation? En Utvärdering av Svensk $\begin{array}{lll}\text { Integrationsdebatt. } & \text { Timbro. } & \text { Retrieved }\end{array}$ http://www.timbro.se/bokhandel/pdf/9175667966.pdf

KINDLER, M., RATChEVA, V. \& PIECHOWSKA, M. (2015). Social Networks, Social Capital and Migrant Integration at Local Level. IRis Working Paper Series, No 6/2015.

KUUSELA, K. (2011), Invandrare och socialt kapital', i Bert Starrin \& Rolf Rønning (Eds.), Socialt Kapital: I ett Välfärdsperspektiv. Stockholm: Liber.

LIN, N. (1999). 'Building a network theory of social capital'. Connections, Vol. 22, No 1, s. 28-51.

LIN, N. (2000). 'Inequality in social capital'. Contemporary Sociology, Vol. 29, No 6, s. 785-796. http://dx.doi.org/10.2307/2654086

LIN, N. (2008). A network theory of social capital. In Dario Castiglione, Jan W. Van Deth \& Guglielmo Wolleb (Eds.) Handbook on social capital. (pp. 50-69). Oxford: Oxford University Press. 
LUNDH, Ch. (2010). Invandringen till Sverige, Stockholm: SNS förlag.

MIGRATIONSVERKET/SWEDISH MIGRATION BOARD (2015). Beviljade Uppehållstillstånd 19802014 ,

www.migrationsverket.se/download/18.39a9cd9514a346077211283/1421152140864/Beviljade+ uppehållstillstånd+1980-2014+flyktingar+m.fl..pdf

LUKE, D. \& HARRIS, J. (2007). 'Network analysis in public health: history, method and application.' The Annual Preview of Public Health, No 28, s. 69-93. http://dx.doi.org/10.1146/annurev.publhealth.28.021406.144132

NANNESTAD, P., HAASE SVENDSEN, G. \& SVENDSEN, T. (2008). 'Bridge over troubled water? Migration and social capital.' Journal of Ethnic and Migration Studies, Vol. 34, No 4, s. 607-631. http://dx.doi.org/10.1080/13691830801961621

PORTES, A. (1998). 'Social capital: its origins and applications in modern sociology.' Annual Review in Sociology, No 24, s. 1-24. http://dx.doi.org/10.1146/annurev.soc.24.1.1

RIKSREVISIONSVERKET (2015). Nyanländas Etablering -Aär Statens Insatser Effektiva? RIR 2015:17, Stockholm.

SCHIERUP, C-U., HANSEN, P. \& CASTLES, S. (2009). Migration, Citizenship and the European welfare State. A European dilemma, Oxford: Oxford University Press.

STARRIN, B. \& RONNING, R. (Eds.) (2011) Socialt Kapital: I ett Välfärdsperspektiv. Stockholm: Liber.

SVENDSEN, G. (2006). 'Studying social capital in situ: a qualitative approach.' Theory and Society, Vol. 35, No 1, s. 39-70. http://dx.doi.org/10.1007/s11186-006-6780-3 